\title{
The Use of Biofiltration Technology and 3-dimensional Cubical Bamboo Shelters for Nursery Phase Productivity Improvement of Giant Freshwater Prawns
}

\author{
Gede Suantika, Pingkan Aditiawati, Malendra Rusni, Rifki R. Arief \& \\ Osman R. Turendro
}

\begin{abstract}
Microbial Biotechnology Research Group, School of Life Sciences and Technology Institut Teknologi Bandung, Jl. Ganesha 10 Bandung, Jawa Barat 40132, Indonesia Email: gsuantika@sith.itb.ac.id
\end{abstract}

\begin{abstract}
This experiment was aimed at finding out the effects of using nitrifying bacteria and Chlorella sp. and the application of a differing number of 3-dimensional cubical bamboo shelters for enhancing the growth performance of Giant Freshwater Prawns (Macrobrachium rosenbergii de Man) during the nursery phase in an indoor system. During 28 days of culture, treatment II (application of 4 shelters $\sim 40 \%$ culture volume occupation) resulted in better prawn growth and culture performance compared to control (no shelter application $)(\mathrm{p}<0,05)$. At the end of the experiment, treatment II showed the highest biomass, specific growth rate, mean body weight and length of prawns with $(1.96+0.05)$ g.cage ${ }^{-1}, 8.24 \%$ BW.day ${ }^{-1},(2.18+0,89) \mathrm{g}$ and $(6.50+0.91) \mathrm{cm}$, respectively. However, these results were not significantly different compared to treatment I (application of 2 shelters $\sim 20 \%$ culture volume occupation). The survival rate after treatment I and II (treatment $\mathrm{I}=90 \%$, and treatment II=92\%) was significantly higher compared to control (78\%). During the experiment the increase of the concentration of ammonium and nitrate was controlled by the addition of nitrifying bacteria and microalgae, which can keep the microbial loop between ammonium reduction by bacteria and nitrate uptake by microalgae in balance. The addition of nitrifying bacteria and microalgae, and the availability of $40 \%$ bamboo shelter occupation in the culture can improve prawn culture productivity.
\end{abstract}

Keywords: nitrifying; Chlorella; shelter; Macrobrachium rosenbergii de Man; nursery.

\section{$1 \quad$ Introduction}

The giant freshwater prawn (Macrobrachium rosenbergii de Man) is one of the freshwater aquaculture commodities that have grown significantly during the last decade. The total world production increased from 82.000 MT in 1998 to $221.000 \mathrm{MT}$ in 2007 [1]. This growth was significantly supported by several advantages attributed to the commodity, such as: (1) able to be cultured in inland areas using different kinds of water sources, (2) availability of current

Received June $6^{\text {th }}, 2011$, Revised December $27^{\text {th }}, 2011,2^{\text {nd }}$ Revision April $18^{\text {th }}, 2012$, Accepted for publication May $1^{\text {st }}, 2012$.

Copyright (C) 2012 Published by LPPM ITB, ISSN: 1978-3043, DOI: 10.5614/itbj.sci.2012.44.2.3 
rearing technologies, (3) availability of broodstock in captivity, (4) suitability of farming for both small and large scale production, (5) suitability for inclusion in a polyculture system, and (6) excellent market opportunities [2].

From an economic point of view, the increased demand of giant freshwater product has triggered the development of rearing technologies, productivity improvement and an expansion of the industry. Even though several adjustments have been made to the rearing process, including the hatchery, nursery, and grow-out stages, in order to improve the quality and quantity of the product, there are still many disadvantages connected with giant freshwater prawn culture [3].

In Asia, including Indonesia, one of the critical hurdles for further industrialization of this sector are the highly unpredictable survival and growth rates of the prawn during the nursery phase. During this stage, the culture is mostly conducted in earthen ponds with a very low rate of make-up water exchange, while using untreated surface water. Apart from that, the culture is conducted without any consideration for ambient factors that might negatively affect the growth and survival of the larvae, such as water quality, disease control and predator control [4]. It is not surprising under these unpredictable and stressful culture conditions, that post-larvae/juvenile productivity during the nursery phase is very low and that it takes a longer culture period to reach the PL40/juvenile stage (1.5-2.0 g). Recently, juvenile production efficiency of the nursery phase in Indonesia was around $15 \%$, or equal to 14 individuals. $\mathrm{m}^{-2}$ (unpublished data, 2010).

Several improvements have been made in order to improve the performance of juvenile production, such as the use of shelter technology [3]. However, the use of this technology was not able to improve significantly the quantity of PL40/juvenile production, with a low stocking density of 20 individuals $/ \mathrm{m}^{-2}$ and a survival rate of $80 \%$ obtained during the laboratory scale trial. The application of this technology was aimed at providing an expansion of the vertical territory for PL in order to avoid cannibalism, however, without consideration for the improvement or manipulation of water quality. Thus, further improvement, either in quality or quantity, of the nursery stage by manipulation of the microbial loop in order to ensure water quality improvement remains a promising possibility. In addition, enlargement of the vertical territory still needs to be considered, because cannibalism is one of the major behavioral issues that can cause problems in intensive prawn culture [5]. Based on the existing rearing conditions described above, the development of a biofiltration technology combined with the application of a 3-dimensional territory substrate in a static culture system adapted for the crucial need of the commercial operation, by creating better and more stable water quality and at the same time 
providing a larger prawn territory horizontally and vertically, need to be considered.

\section{$2 \quad$ Materials and Methods}

\subsection{Macrobrachium rosenbergii de Man Post Larvae 40 days (PL40) stock}

All experiments were performed using Macrobrachium rosenbergii de Man post-larvae 40 (PL40) with an average initial weight and length of $(0.22 \pm 0.07) \mathrm{g}$ and $(2.75 \pm 0.25) \mathrm{cm}$, respectively. The PL40 originated from a commercial hatchery in Sukamandi, located in the northern coastal area of West Java, Indonesia. The post-larvae (PL) were acclimatized for one week prior to stocking in the Laboratory of Aquatic Ecosystem Analysis, School of Life Science and Technology, Institut Teknologi Bandung, Indonesia.

During the trial, the PL were fed with an artificial diet (45\% protein), with a concentration of $5 \%$ of total body weight. Feed was delivered three times a day at 09:00 am, 12:00 am, and 03:00 pm by manually spreading the feed homogenously throughout the rearing cage. During the experiment, there was no water discharge. The trial was conducted with three replicates per treatment during the 28 days of the culture period

\subsection{Nitrifying the Bacteria Culture}

The isolation of nitrifying bacteria as a biotic agent for biofiltration that were used for the trial was done from several water samples taken from a freshwater hatchery in Sukabumi, West Java, Indonesia. All collected water samples were diluted by serial dilution from $10^{-1}$ to $10^{-2}$ in $0,85 \% \mathrm{NaCl}$. The isolation of nitrifying bacteria was done by the pour-plate method, with the inoculation of $0.1 \mathrm{~mL}$ of each diluted water sample in $15 \mathrm{~mL}$, using Winogradsky as the selective medium for the nitrifying bacteria and nutrient agar as the medium for the bacteria purification process. The isolated nitrifying bacteria were incubated at $25{ }^{\circ} \mathrm{C}$ (room temperature) for $3 \times 24$ hours. The cultured nitrifying bacteria were then scaled up in a batch bioreactor system [6] (Figure 1). The system was equipped with aeration lines and filled with $\mathrm{CaCO} 3$ powder for nitrifying the bacteria substrate. The culture was conducted in the laboratory of Microbiology, School of Life Sciences and Technology, Institut Teknologi Bandung, Indonesia. 


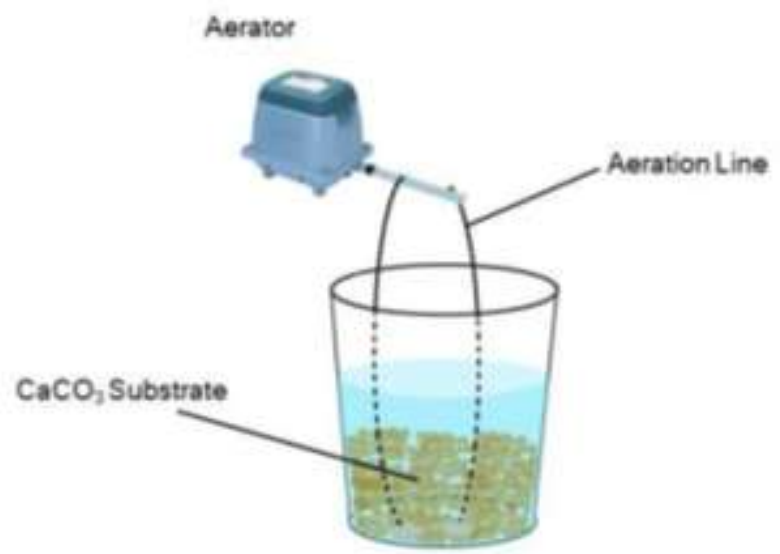

Figure 1 Bioreactor system for nitrifying bacteria.

\subsection{Microalgae Chlorella sp. culture}

Chlorella sp. as an autotrophic organism and agent of nitrate utilization was used for the trial. It was cultured and scaled up using Walne as the medium in a batch photobioreactor system [6] (Figure 2). The system consisted of three major devices: (1) algal rearing flask, (2) fluorescence lamp, and (3) aeration system. The microalgae were isolated and purified from a commercial freshwater hatchery at Sukabumi, West Java, Indonesia, and reared in the Laboratory of Aquatic Ecosystem Analyses, School of Life Sciences and Technology, Institut Teknologi Bandung, Indonesia.

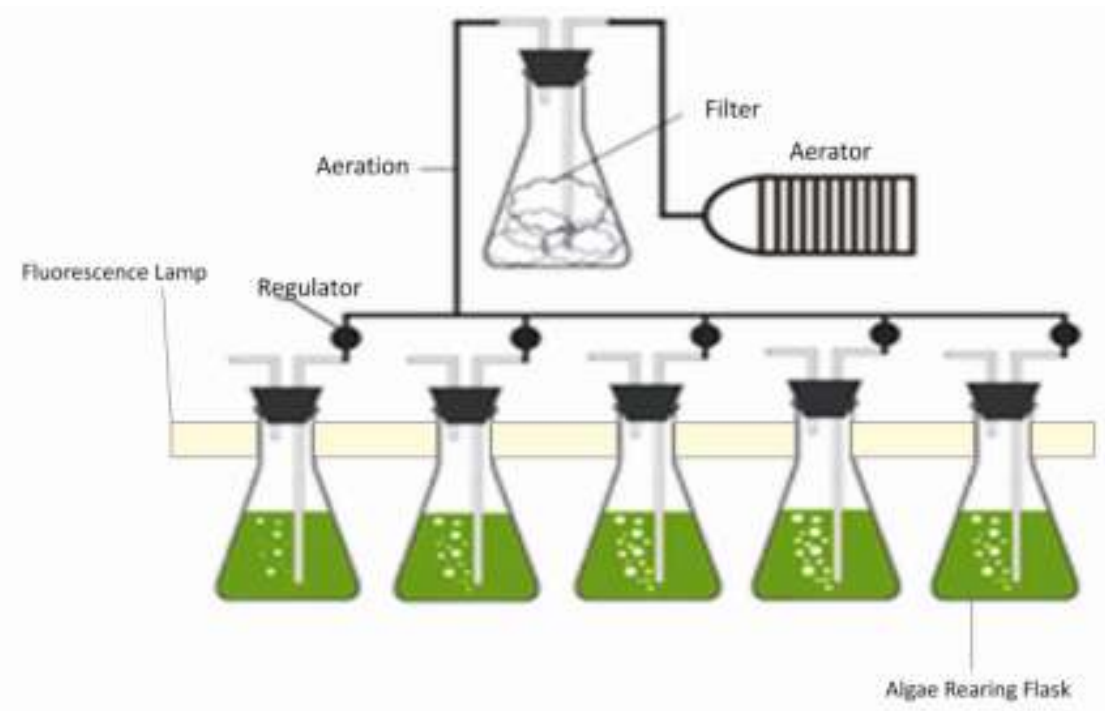

Figure 2 Chlorella sp. batch photobioreactor system. 


\subsection{Experimental Set Up}

In this experiment, several bamboo shelters $\left(0.6 \times 0.6 \times 0.2 \mathrm{~m}^{3}\right)$ were installed inside a number of rearing cages $\left(2 \times 1 \times 0.4 \mathrm{~m} 3 \sim 0,8 \mathrm{~m}^{3}\right)$ that were in turn placed into an indoor $\left(2 \times 5 \times 0.8 \mathrm{~m}^{3}\right)$ tank. The tank was filled with filtered ground water $(0 \mathrm{ppt})$ and maintained at a constant room temperature of $(30 \pm 1)$ ${ }^{\circ} \mathrm{C}$. The dissolved oxygen level was maintained stable at $(6.70 \pm 0.51) \mathrm{mg} . \mathrm{l}^{-1}$ by means of one aeration line per rearing cage and controlled on a weekly basis.

In order to maintain the water quality, nitrifying bacteria $\left(10^{5}\right.$ CFU.ml-1) and Chlorella sp. $\left(10^{4}\right.$ cells. $\left.\mathrm{ml}^{-1}\right)$ were added $24 \mathrm{~h}$ before stocking and on day 14 of the culture period. A schematic outline of the culture system used during the trial is presented in Figure 3.

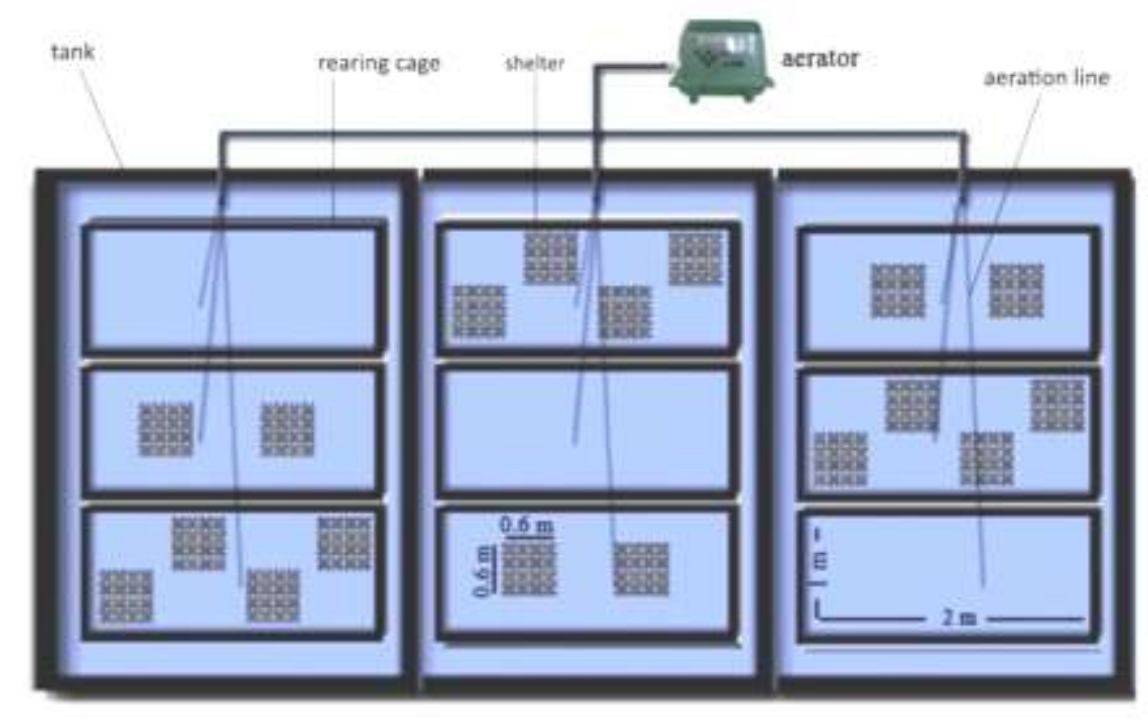

Figure 3 Schematic outline of indoor culture system.

Three rearing cages were placed inside each indoor rearing tank, representing the three treatments of the trial. For treatment I, one rearing cage was equipped with two 3-dimensional cubical bamboo shelters (each $72 \mathrm{dm}^{3}$ in volume, see Figure 4), occupying around $20 \%$ of the total culture volume. For treatment II, one rearing cage was equipped with four 3-dimensional cubical bamboo shelters, occupying around $40 \%$ of the total culture volume. For control, the rearing tank was run without any bamboo shelters. The trial was conducted with three replicates per treatment during a culture period of 28 days. In order to be able to manipulate the microbial loop, especially for breaking down the ammonium accumulation level in the culture through a nitrification process and at the same time uptaking the nitrate accumulation as the end-product of the 
nitrification process, 24 hours prior to PL40 stocking 105 CFU.ml-1 nitrifying bacteria and 104 cells.ml-1 Chlorella sp. were inoculated into each indoor rearing tank in which the three treatments took place. Addition of bacteria and microalgae was conducted twice on the day before stocking and on day 14 of the culture period.

Initial stocking density was arranged differently among the treatments. In control, PL-stocking density was 30 individuals. $\mathrm{ml}^{-1}$, while in treatment I and II, stocking density was increased to 60 individuals.ml-1 (100\% stocking density increment). The PL40 were allowed to grow until the appropriate size was reached, i.e. normal grow-out size averaging $(2.00 \pm 0.91) \mathrm{g}$, meaning that the PL40 were in the last stage of the nursery phase.

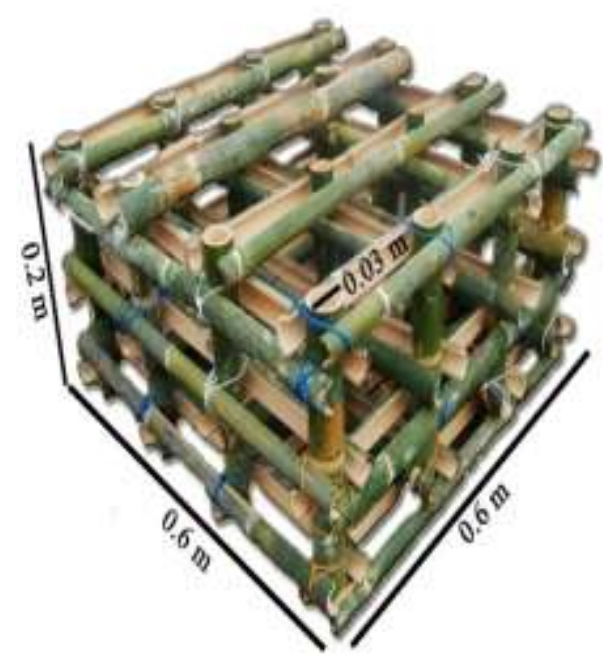

Figure 4 3-dimensional cubical bamboo shelter (modified from [3]).

\subsection{Sampling and Counting}

Several ambient measurements for biological, physicochemical and microbiological parameters were taken during the trial.

\subsubsection{Biological Parameters}

Growth, length, survival rate (SR), and biomass were measured at the beginning of the culture period (day 0) and at the end of the culture period (day 28). Measurements were conducted on all stocked PL and harvested PL. PL growth was calculated by using the following equation [7]:

$$
\operatorname{SGR}(\% \text { day })=[\operatorname{Ln}(\mathrm{W} 2 / \mathrm{W} 1) /(\mathrm{T} 2-\mathrm{T} 1) \times 100]
$$


where:

$\mathrm{SGR}=$ specific growth rate

$\mathrm{W} 1$ = initial live body weight (g) at time $\mathrm{T} 1$ (day)

$\mathrm{W} 2$ = final live body weight $(\mathrm{g})$ at time $\mathrm{T} 2$ (day)

The survival rate of the PL during the trial was calculated by using the following equation [8]:

$$
\mathrm{SR}=\mathrm{Nt} / \mathrm{No} \times 100 \%
$$

where:

$\mathrm{SR}=$ survival rate

No $=$ initial individual quantity

$\mathrm{Nt}=$ final individual quantity

\subsubsection{Physicochemical Parameters}

$\mathrm{pH}$, ammonium $\left(\mathrm{NH}_{4}{ }^{+}\right)$, nitrite $\left(\mathrm{NO}_{2}{ }^{-}\right)$, and nitrate $\left(\mathrm{NO}_{3}{ }^{-}\right)$of the culture water were measured on a weekly basis, starting from day 0 during the experiment. Measurements were conducted directly in the water culture inside the indoor rearing tank. $\mathrm{NH}_{4}^{+}, \mathrm{NO}_{2}^{-}$, and $\mathrm{NO}_{3}^{-}$were measured by using test kits (Aquamerck®, Germany).

\subsubsection{Bacterial Sampling}

Microbiological analyses were performed on a weekly basis by sampling $10 \mathrm{ml}$ water from each rearing tank. Serial dilutions $\left(10^{-1}, 10^{-2}, 10^{-3}, 10^{-4}\right)$ were prepared in a sterile saline solution (1.5\%) from the homogenized water samples and $100 \mu \mathrm{l}$ was plated in duplicate on NA (nutrient agar) (Difco, USA). The plates were incubated at $25^{\circ} \mathrm{C}$ and bacterial counts performed after $48 \mathrm{~h}$.

\subsubsection{Statistical Analysis}

All data were statistically analyzed using one-way ANOVA. Significant differences among means $(p<0.05)$ were tested by Duncan's multiple range test.

\section{$3 \quad$ Results and Discussion}

Aim of this study was to investigate the effects of the addition of nitrifying bacteria and Chlorella sp., and the application of shelters on Macrobrachium rosenbergii de Man culture performance. Special attention was given to the 
effects on (1) specific growth rate, (2) prawn body length, (3) total final biomass, (4) survival rate, and (5) water quality.

\subsection{Growth Performance}

Figure 5 shows the prawn growth performance during the 28-day culture period. At the start of the experiment, the average body weight of the prawns was $(0.22 \pm 0.07) \mathrm{g}$. At the end of the experiment (day 28) the average wet weight gain of the prawns was in the range of (1.8-2.1) $\mathrm{g}$ for all treatments. The highest body wet weight gain was obtained in treatment II, namely $(2.17+0.89) \mathrm{g}$. However, there was no significant difference between treatments.

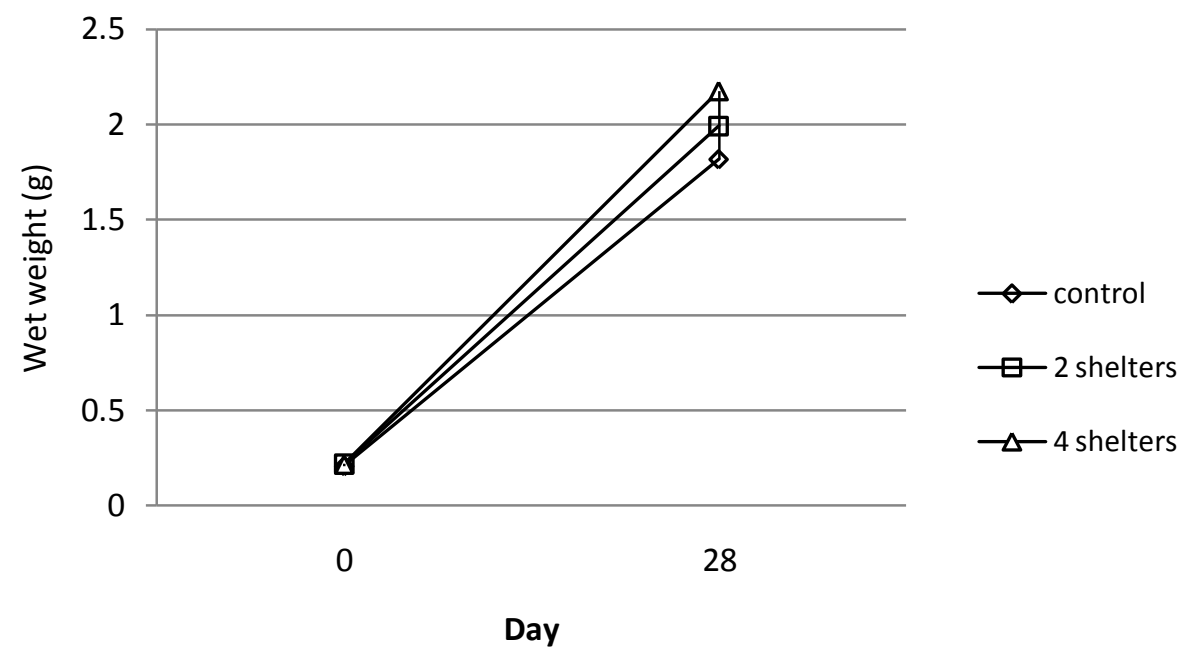

Figure 5 Average total bodyweight of Macrobrachium rosenbergii de Man during 28-day culture period.

Figure 6 shows prawn growth performance during the 28 days of the experiment. At the start of the experiment, the average length of the prawns was equal to $(2.75+0.25) \mathrm{cm}$. At the end of the experiment (day 28) the average length had increased between $6.0 \mathrm{~cm}$ and $6.5 \mathrm{~cm}$. The length of the prawns was $(6.50+0.91) \mathrm{cm},(6.25+1.10) \mathrm{cm},(6.02+1.05) \mathrm{cm}$, respectively. Even though prawn growth and culture performance in treatment II were the highest, there was no significant difference between treatments. Thus, we can see that the addition of nitrifying bacteria, Chlorella sp. and four shelters (occupying 40\% of the total culture volume) in the culture system gave better prawn growth and culture performance. 


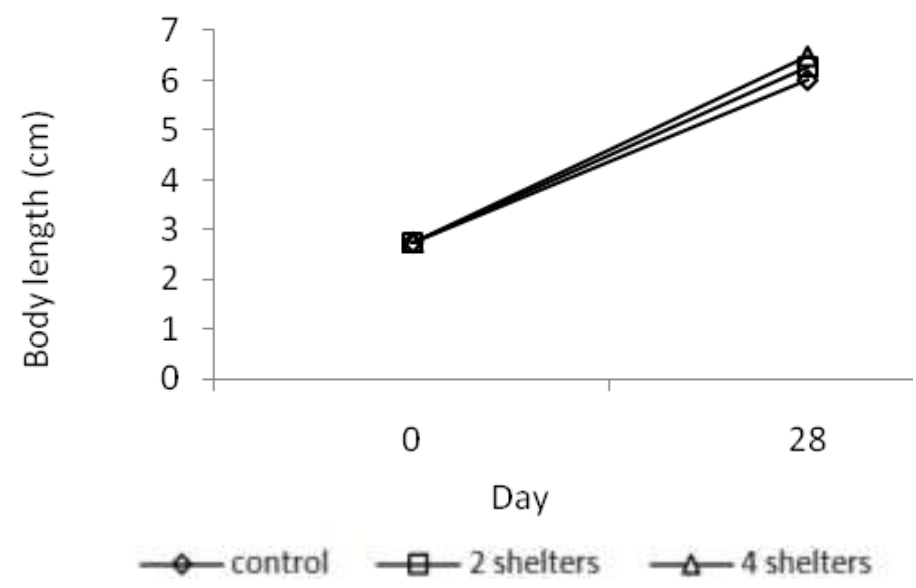

Figure 6 Average total length of Macrobrachium rosenbergii de Man during during 28-day culture period.

Prawn biomass and specific growth rate measured at the end of the culture period are presented in Table 1 . The highest total final biomass $(196+0.09 \mathrm{gr}$. cage $\left.^{-1}\right)$ and the highest SGR $\left(8.24 \%\right.$ BW.day $\left.{ }^{-1}\right)$ were obtained in treatment II (four shelters).

Table 1 Prawn biomass and SGR during 28-day culture period.

\begin{tabular}{cccc}
\hline & $\begin{array}{c}\text { Biomass } \\
\left(\text { (gr. cage }^{-\mathbf{1}}\right)\end{array}$ & $\begin{array}{c}\text { SGR } \\
\left(\boldsymbol{\%} \mathbf{B W} . \mathbf{d a y}^{-\mathbf{1}}\right)\end{array}$ & $\begin{array}{c}\text { Productivity increase } \\
\text { compared to control } \\
(\boldsymbol{\%})\end{array}$ \\
\hline control & $141 \pm 0.03^{\mathrm{a}}$ & 7,74 & $0 \%$ \\
2 shelters & $183 \pm 0.05^{\mathrm{b}}$ & 7,88 & $30 \%$ \\
4 shelters & $196 \pm 0.09^{\mathrm{b}}$ & 8,24 & $39 \%$ \\
\hline \multicolumn{2}{c}{ Note: different letters in the same column denote a significant difference $(p<0.05)$}
\end{tabular}

Based on these results, it can be stated that the addition of nitrifying bacteria and algae was able to provide appropriate culture conditions and affect the juvenile growth performance accordingly in all treatments. The use of the shelters did not contribute significantly to the increase of individual growth and length of the PL40 produced. However, the effect of shelter application did show a significant effect on the increase of total biomass production (30-39\%) compared to control (Table 1). Normally, a higher density of prawns will result in more competition between individuals for space and food [9]. In fact, in this trial, the highest wet weight gain, total biomass and SGR were obtained in treatment II, which had a higher stocking density than control. This was due to the higher number of shelters, which provides more vertical territory and results in less competition and a lower cannibalism rate [3]. At the same time, possible deterioration of water quality caused by excessive accumulation of dissolved 
inorganic nitrogen can be minimized by the addition of nitrifying bacteria and regular addition of Chlorella sp. [10]. Under these conditions, the culture was able to improve carrying capacity for a higher prawn stocking density.

\subsection{Survival Rate}

The survival rate calculation for all treatments at the end of the culture period is presented in Figure 7. Stocking density in control was 39 prawns, and 60 prawn in the other two treatments. The highest survival rate (92\%) was obtained with treatment I, followed by treatment II (90\%), and control (77\%). Based on statistical analysis, the survival rate in control was significantly lower compared to the other treatments $(\mathrm{p}<0.05)$.

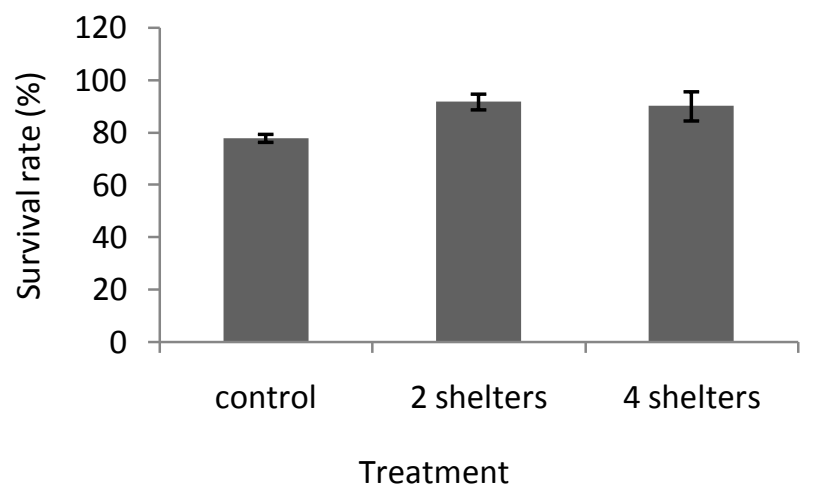

Figure 7 Survival rate of Macrobrachium rosenbergii de Man during 28-day culture period.

In extensive earthen pond cultures, stocking density is one of the most important considerations for productivity improvement, since at higher stocking densities (more than 7-10 ind. $\mathrm{m}^{2}$ ) the mortality rate increases significantly. Based on the results of this experiment, it can be stated that this problem can be minimized by the use of highly developed culture techniques. The application of shelters enables the culture to improve prawn survival capacity significantly. The availability of a larger territory area, vertically and horizontally, will reduce contact possibility of prawns that are reared at high stocking densities and this minimum contact has a direct effect on the reduction of prawn mortality due to cannibalistic behavior [3]. Another effect of vertical surface area expansion by means of 3-dimensional shelters is having more comfortable zones for the newly molted prawns. They use the upper part of the shelter to minimize interaction with other prawns and at the same time receive more dissolved oxygen from the upper layer of the water (unpublished data, 2010). 
Additionally, maintaining acceptable environmental conditions during the culture period can also contribute positively to the biological parameters of the prawns (will be presented in the further results and discussion).

\subsection{Water Quality}

The $\mathrm{pH}$ level during the 28 days of the culture period are shown in Figure 8. The average $\mathrm{pH}$ level remained stable between $7,1-8,8$.

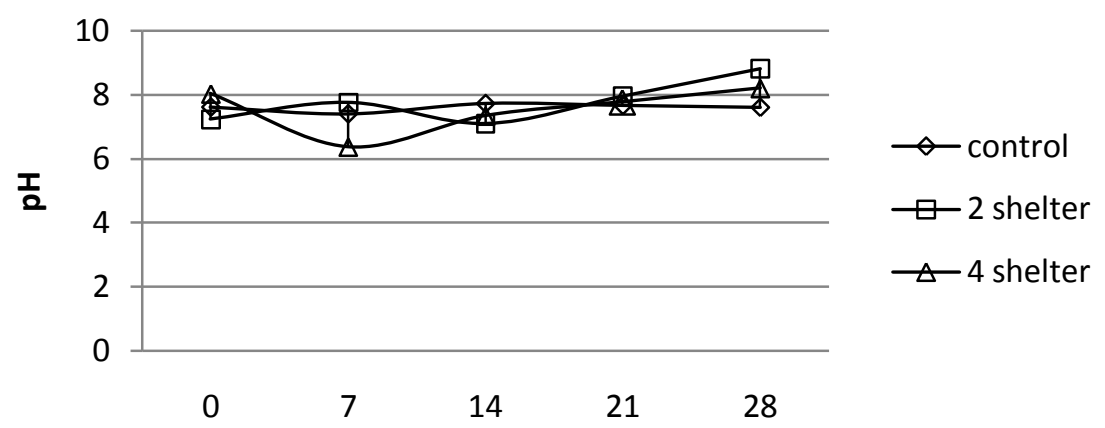

Day

Figure $8 \mathrm{pH}$ concentration during 28-day culture period.

The $\mathrm{pH}$ range in all treatments was still within the tolerance range for prawn cultures, with 7,0-8,5 [11]. The stabilization of the $\mathrm{pH}$ level in culture water can be maintained thanks to the buffering process of $\mathrm{CaCO}_{3}$ that functions as a biofiltration substrate. This process can stabilize the water's acidification because of the nitrification activity and the accumulation of organic matter in animal cultures [12].

The addition of $\mathrm{CaCO}_{3}$ into bacterial growth media must have an important effect on the continuous supply of $\mathrm{C}$ for creating alkaline culture conditions [13]. For prawns, the availability of $\mathrm{CaCO}_{3}$ at a suitable level $\left(100 \mathrm{mg} \cdot \mathrm{L}^{-1}\right)$ in the culture will increase the survival and growth rate up to $90 \%$ and $4.92 \pm 0.12$ mg.day ${ }^{-1}$, respectively [14]. The other advantage of using $\mathrm{CaCO}_{3}$ is that it can minimize calcium deficiency, which is one of the factors contributing to the failure of prawn cultures and is usually compensated with calcium feed supplements [15].

The measured water quality during the culture period is presented in Figure 9. During the experiment the ammonium concentration increased up to $0.05 \mathrm{ppm}$ entering day 7 of the culture period in all treatments, and then decreased and 
remained stable at $0.04 \mathrm{ppm}$ from day 14 until the end of the culture period (Figure 9a). The nitrite level also remained stable and low during the culture period for all treatments (Figure 9b). The nitrite level was stable and remained low at a level of 0-0.30 ppm during the culture period. During the experiment, the nitrate concentration tended to be stable and at the end of the culture period, the nitrate level for all treatments was $10 \mathrm{ppm}$ (Figure 9c).

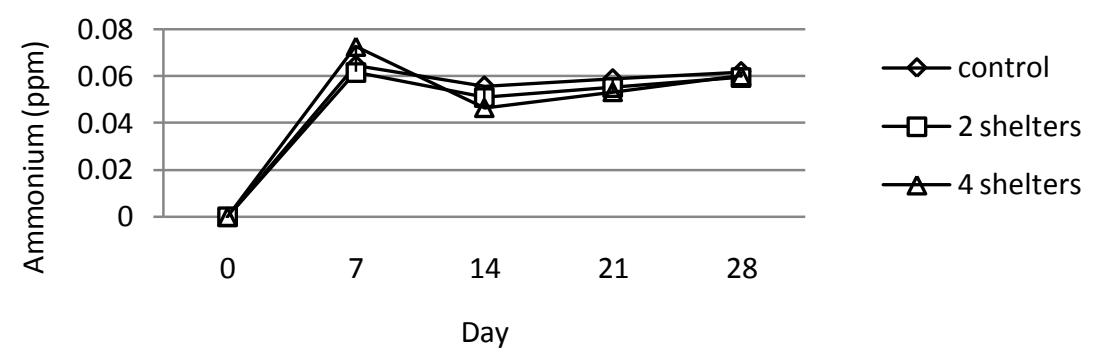

(a)

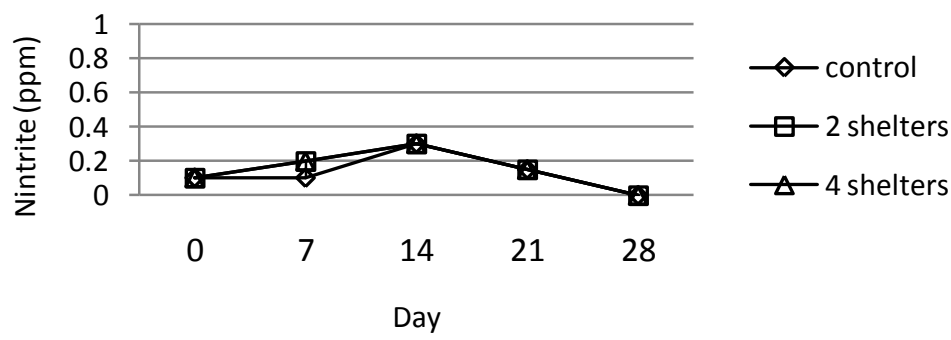

(b)

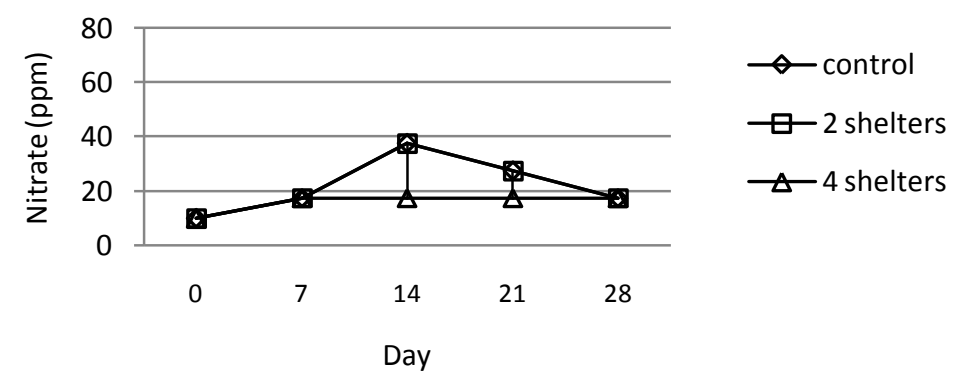

(c)

Figure 9 Ammonium (a), nitrite (b), and nitrate (c) concentration during 28-day culture period.

Generally, all dissolved inorganic nitrate levels remained low and stable during the 28 days of the culture period. The low level of ammonium and nitrite 
indicates that the nitrification process converting ammonium into nitrite and nitrate was working appropriately. This was maintained by means of nitrifying bacteria that were added on a regular basis, i.e. $24 \mathrm{~h}$ before stocking and on day 14 of the culture period. This addition had a positive effect on lowering and stabilizing the ammonium and nitrite concentration in the culture.

The level of nitrate, as the final product of the nitrification process, should increase gradually in the culture water. However, the results show that a relatively low and stable concentration of nitrate was obtained. This can be explained by the treatment that was used during the trial, in which microalgae Chlorella sp. were regularly inoculated along with nitrifying bacteria into the prawn culture. It is well known that microalgae have the ability to uptake nitrate as nutrition [16]. Thus, regular addition of nitrifying bacteria and microalgae Chlorella sp. effectively helped maintaining better water quality and it also contributed to the system's ability to support higher stocking densities (up to $100 \%$ compared to control).

During the 28-day culture period, the concentration of most dissolved inorganic nitrate was within the tolerance range of prawn cultures, except for nitrate in control and treatment I. The tolerance level for ammonium, nitrite and nitrate is below $0,1 \mathrm{ppm}, 0,1-1,7 \mathrm{ppm}$, and below $10 \mathrm{ppm}$, respectively [11].

In general, the use of Zero Water Discharge technology provides stabilization of water quality during the culture period, keeping it within the tolerance ranges of prawns. Due to addition of microalgae and nitrifying bacteria and the application of 3-dimensional shelters a stable culture can be created by means of better water quality and enhancement of biological parameters such as biomass and survival rate. Improvement through the addition of microalgae based on the application of research on nitrifying bacteria in prawn nursery [17] gives more stable inorganic nitrate levels during the culture period. Hence, the stabilization of the water quality and the expansion of vertical territory can contribute to a higher productivity and stocking density, as presented in Table 1. Normally, the average juvenile production efficiency of the nursery phase in the prawn industrial centre in Sukamandi is around $15 \%$, or equal to $14-20$ individuals. $\mathrm{m}^{2}{ }^{2}$ [17]. By using this technology, a higher stocking density can be maintained, which results in a higher total biomass. Thus, a higher carrying capacity can be achieved, even though it did not significantly affect the individual prawn weight gain.

From an economical point of view, the application of 3-dimensional shelters, nitrifying bacteria and microalgae, results in a higher total biomass and survival rate, an increase of the total weight of prawns harvested, a shorter culture period 
and better uniformity of the prawns. A further benefit is that it can help farmers to minimize grading and potential losses during partial harvesting.

\section{Conclusion}

It can be concluded that the addition of nitrifying bacteria and Chlorella sp. as biofiltration agents, combined with the use of 3-dimensional bamboo shelters can enhance the growth and culture performance of Giant Freshwater Prawns (Macrobrachium rosenbergii de Man) during the nursery phase in an indoor hatchery system.

\section{Acknowledgements}

We would like to thank the ITB Alumni Association (IA-ITB) for their financial support through HIBAH IKATAN ALUMNI 2009-2010, and also the Freshwater Prawn Seed Production Centre in the Ciamis district for the use of their facilities and all their hospitality during the experiment.

\section{References}

[1] FAO, Fisheries and Aquaculture Statistics, FAO Yearbook, 2009.

[2] New, M.B., History and Global Status of Freshwater Prawn Farming, Freshwater Prawn Biology and Farming, New, M.B., Valenti, W.C., Tidwell, J.H., D’Abramo, L.R., Kutty, M.N. (Eds.), Blackwell Publsihing Ltd., pp. 1-11, 2010.

[3] Sasmita, P.G., Pengaruh Penggunaan Pelindung terhadap Tingkat Kesintasandan Padat Tebar Udang Galah (Macrobrachium rosenbergii de Man) dalam Skala Laboratorium, Bachelor Thesis, Biology Department, School of Life Sciences and Technology, Institut Teknologi Bandung, Bandung, 2003.

[4] New, M.B. \& Kutty, M.N., Commercial Freshwater Prawn Farming and Enhancement Around the World, Freshwater Prawn Biology and Farming, New, M., B., Valenti, W., C., Tidwell, J., H., D’Abramo, L., R., Kutty, M., N (Eds.), Blackwell Publishing Ltd., pp. 346-375, 2010.

[5] Nair, K.K.C., Branislav, M., Rosenthal, H., Jayalakshmi, K.V., \& Nost, J., Experimental Studies on the Cannibalistic Habit of Macrobrachium rosenbergii (de Man), The Fourth Indian Fisheries Forum Proceeding, Joseph, M.M., Menon, N.R., Nair, N.U.(Eds.), pp. 227-232, 1996.

[6] Suantika, G., Astuti, D.I., Aditiawati, P., \& Sasmita, P.G., Development of Zero-Water Discharge Technology and Nitrifying Bacteria Application in Nursery Phase of The Giant Freshwater Prawn (Macrobrachium 
rosenbergii de Man), in World Aquaculture Meeting Abstract Book, pp. 208, 2009.

[7] Priestley, M.S., Stevenson, A.E., \& Alexander L.G., Growth Rate and Body Condition in Relation to Group Size in Black Widow Tetras (Gymnocorimbusternetzi) and Common Gold Fish (Carrasiusauratus), The Journal of Nutrition, 136(7), pp.20785-20805, 2006.

[8] Habashy, M.M., Growth and Body Composition of Juvenile Freshwater Prawn Macrobrachium rosenbergii, Fed Different Dietary Protein/ Starch, Global Veterinaria, 3(1), pp. 45-50, 2009.

[9] Raanan, Z., \& Cohen, D., Characterization of size Distribution Development the Freshwater Prawn Macrobrachium rosenbergii (de Man) Juvenile Population, Crustaceana, 46(3), pp. 271-287, 1984.

[10] Suantika, G., Aditiawati, P., \& Rusni, M., The Use of Peryphitic Biofiltration Technology for Nursery Phase Improvement of Giant Frehwater Prawn (Macrobrachium rosenbergii de Man) through the Application of Nitrifying Bacteria and Chlorella sp. in Outdoor System, Asia Pasific Aquaculture Meeting Abstract Book, pp. 547, 2011.

[11] Boyd, C. \& Zimmermann, S., Grow-out Systems-Water Quality and Soil Management. Freshwater Prawn Biology and Farming, New, M.B., Valenti, W.C., Tidwell, J.H., D’Abramo, L.R., Kutty, M.N (Eds.), Blackwell Publishing Ltd., pp. 239-253, 2010.

[12] Suantika, G., Development of a Recirculation System for The Mass Culturing of The Rotifer Brachionusplicatilis, Animal Production Department, Faculty of Agriculture and Applied Biological Sciences, Universiteit Gent, Belgium, pp. 1-273. 2001.

[13] Wilton, S. \& Morey R., Biofilter Operating Procedures, Recirculation Today, PR Aqua Technology Ltd Praqua, p. 29, 2000.

[14] Zimmerman S., Le Boute, E.M. \& Souza, S.M.G., Effects of Two Calcium Levels in Diets and Three Calcium Levels $N$ Culture Water on The Growth of Freshwater Prawn, Macrobrachium rosenbergii (de Man). World Aquaculture 1994, New Orleans, p. 196, 1994.

[15] Adhikari, S., Chaurasian V.S., Naqvi A.A. \& Pilai B.R., Survival and Growth of Macrobrachium rosenbergii (de Man) Juvenile in Relation to Calcium Hardness and Bicarbonate Alkalinity, Turk. J. Fish. Aquat. Sci., 7, pp. 23-26, 2007.

[16] Wetzel, R.G, Limnology: Lake and River Ecosystem, 2nd ed., California Academic Press, pp. 275-285, 2001. 
[17] Sasmita, P.G., Pengembangan Teknologi 'Zero-Water Discharge' dan Aplikasi Bakteri Nitrifikasi dalam Tahap Pendederan Udang Galah (Macrobrachium rosenbergii de Man), Master Thesis, Biology Department, School of Life Sciences and Technology, Institut Teknologi Bandung, Bandung, 2003. 